zeszyt 152 , 2018, 105-118

doi: 10.4467/20833113PG.17.033.8256s

Instytut Geografii i Gospodarki Przestrzennej UJ

Wydawnictwo Uniwersytetu Jagiellońskiego

\title{
GEOMORFOLOGICZNE I GEOLOGICZNE UWARUNKOWANIA GENTRALNEJ CZEŚSCI MIĘDZYRZECKIEGO REJONU UMOCNIONEGO (MRU), POLSKA ZACHODNIA
}

\author{
Mateusz Mlec:ak
}

\section{Geomorphological and geological conditions of the central part of Międzyrzecz Fortified Region, Western Poland}

\begin{abstract}
The Międzyrzecz Fortified Region (Festungsfront the Oder-Warthe-Bogen in German) is located between the Odra and Warta Rivers. This fortification system was built by the Germans in order to protect the eastern border of the Third Reich, in the years 1934-1944. The area between Kursko and Lubrza (the central part of the Międzyrzecz Fortified Region) was the most fortified one. In this paper the author discusses geomorphological and geological factors, which determined the location of bunkers in the studied area. The morphology, lithostratigraphy and hydrogeology of the central part of the Międzyrzecz Fortified Region were described in detail. Moreover, the depositional processes and sedimentary environments during the Weichselian were identified. The placement of pillboxes in the central part of the Międzyrzecz Fortified Region was conditioned by geomorphological factors and to a lesser importance - by geological ones. The bunkers connected by underground system were built on the upland, whereas isolated objects were located in valleys and in the vicinity of lakes and watercourses. An additional factor that could affect the location of bunkesr was provided by hydrogeological conditions.
\end{abstract}

Keywords: Międzyrzecz Fortified Region, geomorphology, geology

Zarys treści: W latach 1934-1944 na obszarze pomiędzy rzekami Odrą - na południu, i Wartą na północy, państwo niemieckie wybudowało system umocnień chroniący wschodnią granicę III Rzeszy - Międzyrzecki Rejon Umocniony (niem. Festungsfront im Oder-Warthe-Bogen). 
Najsilniej ufortyfikowany został odcinek centralny pomiędzy Kurskiem i Lubrzą. W niniejszej pracy podjęto próbę określenia wpływu warunków geomorfologicznych i geologicznych na lokalizację bunkrów na terenie przeprowadzonych badań. Dokładnie opisano obszar centralnej części Międzyrzeckiego Rejonu Umocnionego pod kątem morfologicznym, litostratygraficznym i hydrogeologicznym. Rozmieszczenie obiektów bojowych Międzyrzeckiego Rejonu Umocnionego w jego centralnej części uwarunkowane było czynnikami geomorfologicznymi oraz w mniejszym stopniu geologicznymi. Bunkry połączone z sobą systemem podziemnym zbudowano na wysoczyźnie, podczas gdy wolnostojące obiekty zlokalizowane były w obniżeniach terenu oraz w sąsiedztwie cieków i zbiorników wodnych. Dodatkowym czynnikiem, który mógł mieć wpływ na lokalizację bunkrów, były warunki hydrogeologiczne.

Stowa kluczowe: Międzyrzecki Rejon Umocniony, geomorfologia, geologia

\section{Wstęp}

Międzyrzecki Rejon Umocniony (MRU) to obszar ciekawy zarówno pod względem historycznym, jak i krajobrazowym. Zwłaszcza jego centralna, najsilniej ufortyfikowana część znajduje się na terenach o urozmaiconej rzeźbie terenu. Jest również miejscem o interesującej budowie geologicznej. Największy wpływ na jej cechy miały zlodowacenia południowo- i środkowopolskie, kiedy to wielokrotnie nasuwający się na ten obszar lądolód powodował liczne zaburzenia glacitektoniczne (m.in. Dyjor, Pruc 1978; Ciuk 1995; Winnicki 2004). Ostatnie zlodowacenie jedynie przemodelowało powstałe wcześniej formy terenu, pozostawiając osady czołowomorenowe, sandrowe oraz glinę zwałową. To właśnie na tych obszarach w latach 1934-1944 armia III Rzeszy wybudowała jeden z największych na świecie systemów umocnień. W ich skład wchodzą bunkry, schrony, podziemne tunele i korytarze oraz liczne zapory i przeszkody, które miały służyć obronie ówczesnej wschodniej granicy państwa niemieckiego.

Obszar Międzyrzeckiego Rejonu Umocnionego znajduje się w zachodniej Polsce, na pograniczu Pojezierza Łagowskiego i Bruzdy Zbąszyńskiej, wchodzących w skład makroregionu Pojezierza Lubuskiego (Kondracki 2002). Pod względem geomorfologicznym znajduje się w północnej części Wysoczyzny Lubuskiej, w obrębie Wzgórz Osieńsko-Sulechowskich (Bartkowski 1970).

Istnieje wiele publikacji dotyczących Międzyrzeckiego Rejonu Umocnionego. Do najważniejszych z nich należy szczegółowe opracowanie Miniewicza i Perzyka (1993), w którym autorzy skupiają się na aspektach historycznych oraz budowlanych. Podobną tematykę poruszał także Leibner (2000). Jurga i Kędryna w swojej pracy (2005) dokładnie zinwentaryzowali obiekty militarne, pokazując układy pomieszczeń oraz ich wyposażenie bojowe, rekonstruując także obiekty zniszczone oraz niedostępne. W 2012 r. ukazały się kolejne, interdyscyplinarne publikacje Jurgi (2012 a, b) dotyczące MRU. Wszystkie wymienione opracowania pozwoliły na szczegółowe 
poznanie MRU pod kątem budownictwa militarnego. Brakowało jednak do tej pory analizy lokalizacji tej linii obronnej w kategorii geomorfologii i geologii terenu.

Celem niniejszej pracy jest próba określenia, w jakim stopniu naturalne uwarunkowania morfologiczne i geologiczne miały wpływ na lokalizację bunkrów na tym obszarze. Studium oparto na szczegółowej analizie geomorfologicznej terenu centralnej części Międzyrzeckiego Rejonu Umocnionego oraz obszarów sąsiednich. Przeanalizowano także warunki geologiczne występujące na tym terenie.

\section{Metody badawcze}

Prace badawcze prowadzone były w latach 2014-2016. Obejmowały one kwerendę literatury, prace terenowe oraz kameralne. Kwerenda literatury polegała na studiowaniu dotychczasowych publikacji z obszaru badań, zarówno tych dotyczących aspektów geologiczno-geomorfologicznych, jak i historycznych. Prace terenowe obejmowały analizę sedymentologiczną przeprowadzoną w dwóch nieczynnych żwirowniach w Glińsku i Nietoperku (ryc. 1), jedynych odsłonięciach na terenie badań. Badania te pozwoliły na szczegółowe poznanie litologii centralnej części MRU.

Ważnymi elementami prac kameralnych były analiza oraz przetwarzanie danych kartograficznych. Były to mapy topograficzne w skali 1: 10000 oraz 1: 25 000, cztery arkusze $S$ szegótowej mapy geologicznej Polski w skali 1: 50 000, mapy geośrodowiskowe 1: 50 000, mapy hydrograficzne w skali 1: 50 000, a także mapy, plany oraz szkice umocnień MRU.

\section{Charakterystyka geomorfologiczno-geologiczna}

\section{Cechy rzeźby terenu}

Obszar centralnej części Międzyrzeckiego Rejonu Umocnionego charakteryzuje się zróżnicowaną morfologią. Jednymi z najważniejszych form terenu, kształtujących obraz tego obszaru, są wały moreny czołowej, budujące najwyższe partie terenu (ryc. 2). Są to głównie moreny czołowe spiętrzone (Żynda 1967; Dyjor, Pruc 1978). Należy zwrócić uwagę, że pagórki interpretowane jako wały moreny czołowej są zorientowane z północnego zachodu na południowy wschód, nieco wygięte na południe. Wały morenowe, osiągające maksymalne wysokości 150,7 m n.p.m., znajdują się na zachód od miejscowości Wysoka i Boryszyn. Jest to wschodni kraniec wałów moreny czołowej spiętrzonej (Żynda 1967; Dyjor, Pruc 1978), które ciągną się dalej na zachód, osiągając w swoim kulminacyjnym punkcie wysokość 227 m n.p.m., co czyni te wzgórza najwyższą partią całej Wysoczyzny Lubuskiej. Pagórki moreny 
czołowej spiętrzonej wynurzają się również na północnej i północno-zachodniej krawędzi wysoczyzny, nazwanej przez Bartkowskiego (1964) Wyspą Wysoczyznową Rusinowską, pomiędzy Lubrzą i Jordanowem (ryc. 2). Kolejny ciąg pagórów morenowych znajduje się pomiędzy Kurskiem i Wysoką. Wzniesienia te osiągają wysokości 100-115 m n.p.m. i również wykazują zorientowanie NW-SE, rzadziej W-E. Wysoczyzna polodowcowa jest typu falistego. W morfologii wyraźnie zaznaczają się wzniesienia izolowane obniżeniami. Na badanym obszarze można wyróżnić cztery takie strefy. Teren na zachód od Kurska i północ od Piesek to wschodni kraniec Wysoczyzny Trzemeszeńskiej. Najwyższy punkt znajdujący się w tym rejonie wynosi 107,9 m n.p.m. Wysoczyzna kończy się wyraźnym wcięciem morfologicznym wykorzystywanym przez Strugę Jeziorną. W kierunku południowo-wschodnim przechodzi ona w Wyspę Wysoczyznową Kaławską (Bartkowski 1956), osiągając maksymalne 137,5 m n.p.m. wysokości w okolicach Nietoperka (ryc. 1; ryc. 2).

Kolejnym obszarem wysoczyzny są wzniesienia na linii od Lubrzy przez Rusinów po Glińsk. Jest to Wyspa Wysoczyznowa Rusinowska, której wysokości oscylują w granicach 110-130 m n.p.m., a lokalnie sięgają nawet 138,5 m n.p.m. (ryc. 1). Ostatnim obszarem wysoczyznowym jest teren, na którym znajduje się miasto Międzyrzecz. Został on wyodrębniony w rozległym obniżeniu terenu, gdzie wysokości nie przekraczają 60 m n.p.m. Warto zauważyć, że formy związane z akumulacją wodnolodowcową są ulokowane głównie w północnej części analizowanego odcinka MRU i obszarów do niego przyległych. Znajdują się tutaj zarówno kemy, jak i ozy oraz równiny wodnolodowcowe. Na zachód od miejscowości Święty Wojciech, na południe od rzeki Obry Bartkowski (1956) wyróżnił kemy. Są to niewielkie, owalne pagórki i współwystępujące w ich sąsiedztwie zagłębienia bezodpływowe. Wysokości względne tych pagórków nie przekraczają $10 \mathrm{~m}$, a średnice kilkanaście do kilkudziesięciu metrów. W okolicach miejscowości Święty Wojciech występuje forma interpretowana przez Bartkowskiego (1956) jako oz i nazwana jest przez niego ozem wojciechowskim (ryc. 2). Ciąg pagórków ozowych przecięty jest przez obniżenie, początkowo wypreparowane jako niewielkie niecki bezodpływowe, a w części południowej w postaci wyraźnej rynny.

W skład równin wodnolodowcowych włączono zarówno sandry, jak i terasy kemowe. Żynda i Pruc (1967) wyróżnili powierzchnię zbudowaną z osadów sandrowych po obu stronach Rynny Staropolskiej (ryc. 2; ryc. 3). Obszar sandru nazwanego pieskowskim (Bartkowski 1964; Żynda 1967) ciągnie się od miejscowości Pieski na północ aż do terenów na południe od Staropola. Dalej, sandr ten wypełnia dno części Rynny Jordanowsko-Niesulickiej (ryc. 2) w kierunku na wschód od Staropola, przez Nowy Dworek aż po Jordanowo. Ta strefa doliny sandrowej przecina obszar moren czołowych i wysoczyzny polodowcowej. Wysokości bezwzględne sięgają od 80 do 100 m n.p.m., a szerokość rynny nie przekracza 2,5 km. Nisko położone obszary sandrowe znajdują się także w południkowo biegnącej części Rynny Jordanowsko-Niesulickiej na południe od Staropola. 
Terasa kemowa usytuowana jest na skraju Wyspy Wysoczyznowej Kaławskiej pomiędzy Kurskiem a Nietoperkiem (Bartkowski 1956, 1964). Ta wydłużona forma zorientowana jest w kierunku północny zachód - południowy wschód. Rozpoczyna się ona na południowy wschód od jeziora Kursko i w części południowej osiąga wysokość do 84 m n.p.m. Terasa jest wzniesiona około 20-30 m ponad dno Obniżenia Obry sąsiadującego z nią od północy (Bartkowski 1956). W obrębie powierzchni terasy wypreparowane są niewielkie zagłębienia.

Na obszarze badań znajdują się trzy rynny polodowcowe: Nietoperska, Staropolska i Jordanowsko-Niesulicka (ryc. 2).

Rynna Nietoperska rozpoczyna się na południe od miejscowości Święty Wojciech. Dalej ciągnie się ona w kierunku południowo-zachodnim przez jezioro Staw Kęszyca, zmienia kierunek na południowy, by na północ od Nietoperka skręcić na wschód, przecinając terasę kemową. W dnie tej rynny znajdują się liczne jeziora, m.in. Stoki i Nietoperek Lewy.

Rynna Staropolska ukierunkowana jest z północy na południe. Rozpoczyna się małym jeziorem Pieski łączącym się kanałem z większym jeziorem - Kęszyckim, a dalej z jeziorem Krzaczastym (ryc. 2). Następnie w kierunku południowym dno rynny nie jest wypełnione wodami jeziornymi aż do Wysokiej, gdzie położone jest jezioro Paklicko Małe. Dalej na południe dnem rynny płynie rzeka Paklica. W tym miejscu obniżenie to łączy się z Rynną Jordanowsko-Niesulicką. Całkowita długość rynny wynosi ok. $7 \mathrm{~km}$; jest ona szeroka na 150-750 m, głęboka na 8-12 m, a nachylenie jej stoków wynosi 6-24․

Trzecia rynna - Jordanowsko-Niesulicka - poczynając od Jordanowa w kierunku Staropola, zorientowana jest równoleżnikowo. Na tym odcinku znajduje się największe jezioro - Paklicko Wielkie. Rynna następnie łączy się z Rynną Staropolską i zmienia kierunek na południowy. Całkowita długość tej formy wynosi ok. 18 km, z czego ok. 12 km znajduje się na analizowanym obszarze. Rynna osiąga szerokość w 400-2000 m, głębokość 10-30 m, a nachylenie stoków w przedziale 6-25․ Jej dno jest prawie płaskie, w większości podmokłe i zatorfione.

\section{Cechy budowy geologicznej}

Na powierzchni odsłaniają się osady mioceńskie zlodowaceń południowopolskich, osady stadiału Warty zlodowacenia Odry, zlodowacenia Wisły oraz holoceńskie osady organiczne (Studencki 2000; Bartczak 2003a, b; Chmal 2003a, b; Salwa 2008; ryc. 3). Ostatni postój lądolodu na tym obszarze wystąpił u schyłku fazy leszczyńskiej, a więc przed 20-19 ka BP (Kozarski 1995; Marks i in. 2016).

Osady mioceńskie są przefałdowane wraz z osadami zlodowaceń południowopolskich w obrębie moren spiętrzonych. Wskutek glacitektonicznego wyciśnięcia osady te odsłaniają się na powierzchni niedaleko Zarzynia i Glińska (ryc. 3). Na serię 
osadów mioceńskich składają się piaszczyste osady podwęglowe, węgle brunatne, mułki i drobnoziarniste piaski nadwęglowe oraz iły (Dyjor, Pruc 1978).

Osady zlodowaceń południowopolskich, którymi są: żwiry, piaski, mułki, iły i gliny, odsłaniają się na powierzchni również w obrębie moren spiętrzonych. Na skutek działalności lądolodu osady te zostały wyciśnięte i ustawione niemal pionowo. W okolicach Lubrzy i Rusinowa ich miąższości w otworach wiertniczych dochodzą do kilkudziesięciu metrów (nawet do $80 \mathrm{~m}$ - por. Chmal 2003a, b). Osady zlodowaceń południowopolskich na powierzchni odsłaniają się pomiędzy miejscowościami: Zarzyń, Wysoka, Staropole, Lubrza, Rusinów i Glińsk. Występują także w okolicach Boryszyna, Nowego Dworku oraz Gościkowa (ryc. 3).

Glina zwałowa stadiału Warty odsłania się na powierzchni w obszarze moreny spiętrzonej w okolicach Zarzynia oraz na Wysoczyźnie Trzemeszańskiej w okolicach Piesek. Jest to silnie zapiaszczony diamikton o szarobrunatnej barwie (Chmal 2003 a).

Glina zwałowa zlodowacenia Wisły ma barwę brązową, żółtobrązową, żółtoszarą lub rdzawą. Jest silnie piaszczysta, często pyłowata, niekiedy ilasta. Poza tym zawiera warstwy żwiru, a także dużo głazów, których średnice przekraczają czasami 3 m (Chmal 2003a, Bartczak 2003a). Glina tworzy ciągły pokład o miąższościach dochodzących do 5 lub nawet 10 m. Można to zaobserwować na obszarze Wyspy Wysoczyznowej Kaławskiej (ryc. 4). Glina zwałowa buduje najwyższe partie wysoczyzn oraz występuje w obrębie moreny spiętrzonej w okolicach Zarzynia i Staropola, gdzie osiąga niewielkie miąższości i znajduje się na zboczach wzniesień.

Piaski, żwiry, mułki i gliny wodnolodowcowe budują moreny czołowe, sandry, terasę kemową oraz kemy i oz (ryc. 3). Są to głównie drobnoziarniste piaski o barwie żółtobrunatnej i żółtej, rzadziej szarej. Niekiedy w ich obrębie znaleźć można pakiety żwirów (moreny czołowe, sandry, oz) oraz mułków (kemy). W osadach morenowych znajdują się także głazy narzutowe (Chmal 2003a). Osady tego wydzielenia zostały dokładnie rozpoznane w stanowiskach w Nietoperku oraz w Glińsku. Piaski i żwiry najwyższej terasy rzecznej występują w dolinie nienazwanego cieku wodnego w okolicy Nietoperka. Są to głównie szare, drobnoziarniste piaski, lokalnie ze żwirami, zawierające także domieszki materiału organicznego (Bartczak 2003a). Piaski, mułki i iły zastoiskowe zlodowacenia Wisły znajdują się w okolicach Świętego Wojciecha i Międzyrzecza w rozległym Obniżeniu Obry (Bartkowski 1956). W centrum basenu znajdują się szare iły warwowe, które w kierunkach brzeżnych ustępują miejsca mułkom i piaskom mułkowym (Bartkowski 1956). Kreda jeziorna występuje w dnach rynien glacjalnych. Najczęściej zalega pod niewielką warstwą torfów. Maksymalna miąższość kredy jeziornej została stwierdzona w okolicach Lubrzy i wyniosła 6,4 m (Chmal 2003a). Na powierzchni terenu występuje w okolicach Jordanowa (ryc. 3).

Torfy i namuły holocenu występują w obniżeniach terenu, dnach rynien glacjalnych, sąsiedztwie cieków wodnych, bądź wzdłuż linii brzegowych jezior. Najwięcej tych osadów znajduje się w dnie Rynny Jordanowsko-Niesulickiej, wykorzystanej obecnie przez rzekę Paklicę. Niekiedy torfy zalegają na kredzie jeziornej (okolice 


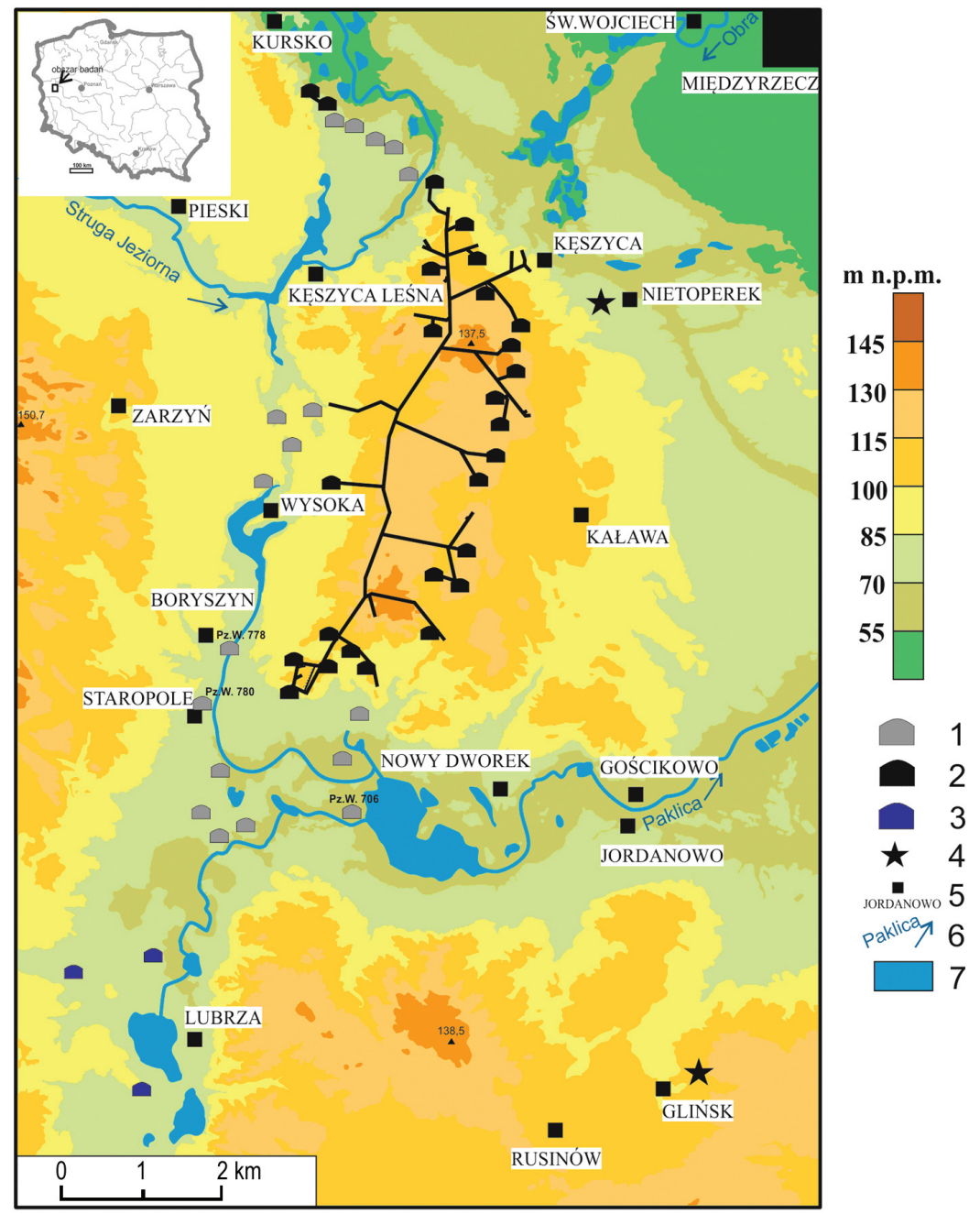

Ryc. 1. Mapa hipsometryczna obszaru badań z lokalizacją bunkrów

Fig. 1. Hypsometric sketch of the studied area with the location of bunkers

Objaśnienia: 1 - bunkry centralnego odcinka MRU niepołączone z sobą; 2 - bunkry centralnego odcinka MRU połączone tunelami komunikacyjnymi; 3 - bunkry południowego odcinka MRU; 4 - lokalizacja odsłonięć; 5 - miejscowości; 6 - rzeki wraz z kierunkami ich płynięcia; 7 - jeziora.

Explanations: 1 - separate bunkers of the central part of the fortified region; 2 - tunnel-connected bunkers of the central part of the fortified region; 3 - bunkers of the southern part of the fortified region (not included in this study); 4 - studied sites; 5 - towns and villages; 6 - rivers and direction of present-day drainage; 7 - lakes. 


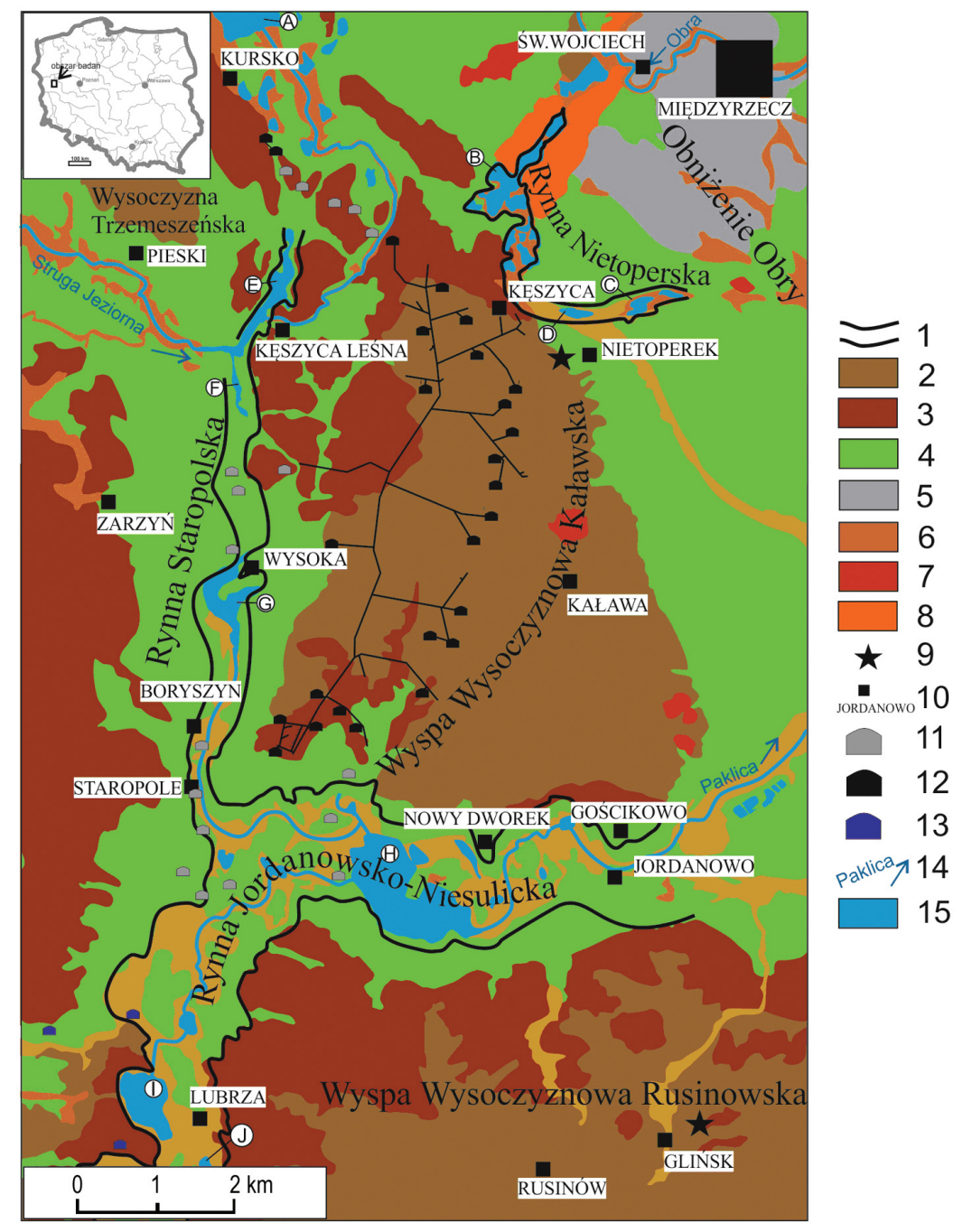

Ryc. 2. Szkic geomorfologiczny centralnej części Międzyrzeckiego Rejonu Umocnionego Fig. 2. Geomorphological sketch of the central part of the Międzyrzecz Fortified Region Objaśnienia: Formy rzeźby terenu: 1 - rynna polodowcowa; 2 - wysoczyzna polodowcowa; 3 - morena czołowa; 4 - równina wodnolodowcowa; 5 - równina zastoiskowa; 6 - równina torfowa; 7 - kem; 8 - oz. Inne symbole; 9 - lokalizacja odsłonięć; 10 - miejscowości; 11 - bunkry centralnego odcinka MRU niepołączone z sobą; 12 - bunkry centralnego odcinka MRU połączone tunelami komunikacyjnymi; 13 - bunkry południowego odcinka MRU; 14 - rzeki wraz z kierunkami ich płynięcia; 15 - jeziora: A - Kursko, B - Staw Kęszyca, C - Nietoperek Lewy, D - Stoki, E - Kęszyckie, F - Krzaczaste, G - Paklicko Małe, H - Paklicko Wielkie, I - Goszcza, J - Lubie.

Explanations: Landforms: 1 - tunnel valley; 2 - till plain; 3 - end moraine; 4 - outwash plain; 5 - glaciolacustrine plain; 6 - lacustrine plain; 7 - kame; 8 - esker; 9 - studied sites; 10 - towns and villages; 11 - separate bunkers of the central part of the fortified region; 12 - tunnel-connected bunkers of the central part of the fortified region; 13 - bunkers of the southern part of the fortified region; 14 - rivers and direction of present-day drainage;s 15 - lakes: A - Lake Kursko, B - Lake Staw Kęszyca, C - Lake Nietoperek Lewy, D - Lake Stoki, E - Lake Kęszyca, F - Lake Krzaczaste, G - Lake Paklicko Małe, H - Lake Paklicko Wielkie, I - Lake Goszcza, J - Lake Lubie. 


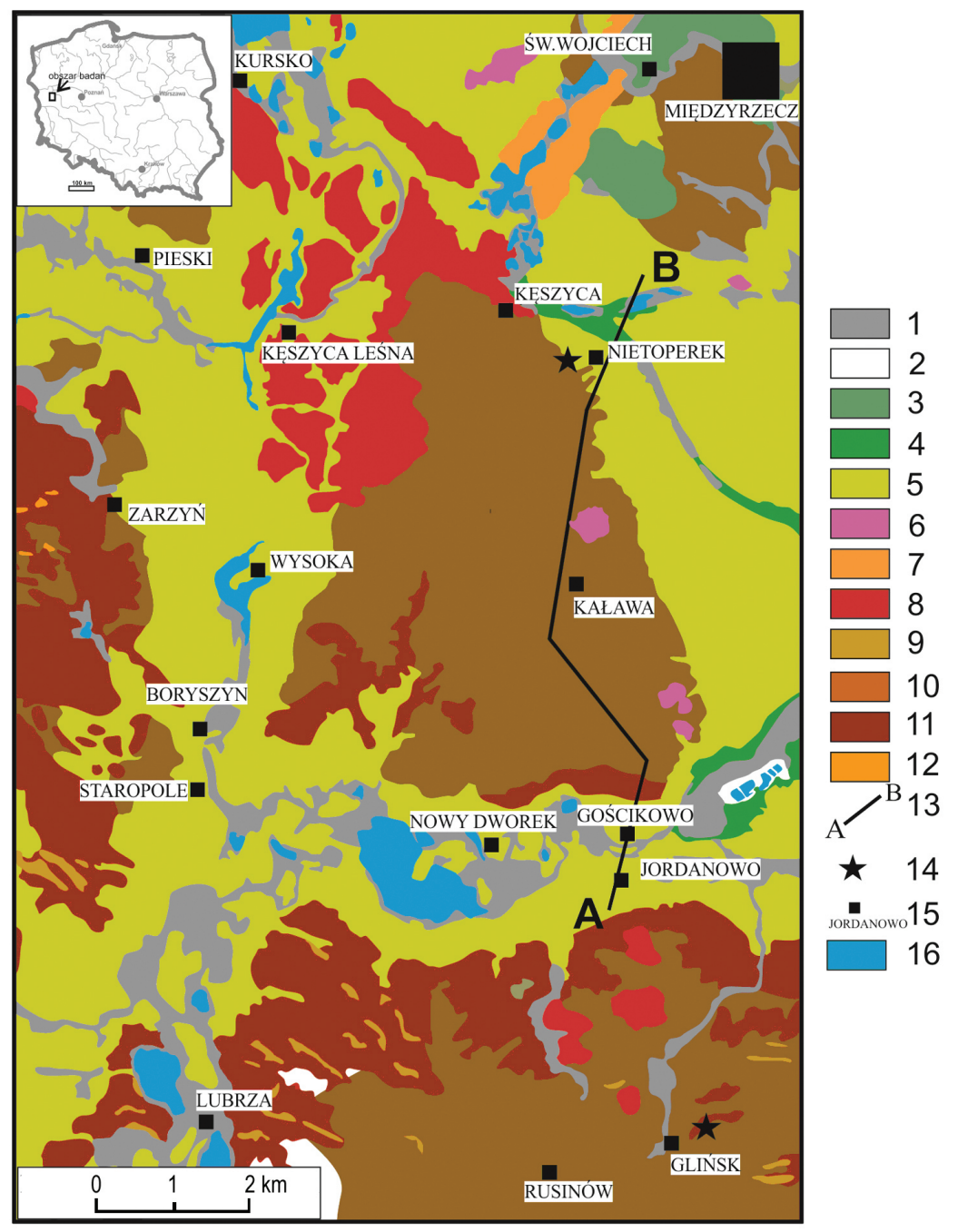

Ryc. 3. Szkic geologiczny centralnej części Międzyrzeckiego Rejonu Umocnionego Fig. 3. Geological sketch of the central part of the Międzyrzecz Fortified Region Objaśnienia: Wydzielenia litologiczne - holocen: 1 - torfy i namuły; 2 - kreda jeziorna. Zlodowacenie Wisły; 3 - piaski, mułki i iły zastoiskowe; 4 - piaski i żwiry najwyższej terasy rzecznej; 5 - piaski, mułki i żwiry glacifluwialne; 6 - piaski, żwiry i mułki kemów; 7 - piaski i żwiry ozów; 8 - piaski, żwiry i gliny moren czołowych; 9 - glina zwałowa. Stadiał Warty zlodowacenia Odry; 10 - glina zwałowa. Zlodowacenia południowopolskie; 11 - żwiry, piaski, mułki, iły i gliny moren spiętrzonych. Miocen; 12 - mułki, iły, piaski i węgiel brunatny. Inne symbole; 13 - linia przekroju geologicznego A-B, przedstawionego na ryc. 4; 14 - lokalizacja odsłonięć; 15 - miejscowości; 16 - jeziora.

Explanations: Lithostratigraphy - Holocene: 1 - peat and silt; 2 - lacustrine chalk. Weichselian Glaciation; 3 - sand, silt and clay (glaciolacustrine); 4 - sand and gravel (fluvial, upper terrace); 5 - sand, silt and gravel (glaciofluvial); 6 - sand, gravel and silt (kame); 7 - sand and gravel (esker); 8 - sand, gravel and till (end moraine); 9 - till. Warthe Stadial of Saale Glaciation; 10 - till. South-Polish Glaciations; 11 - gravel, sand, silt, clay and till (push moraine). Miocene; 12 - silt, clay, sand and brown coal; 13 - cross-section line (fig. 4); 14 - studied sites; 15 - towns and villages; 16 - lakes. 


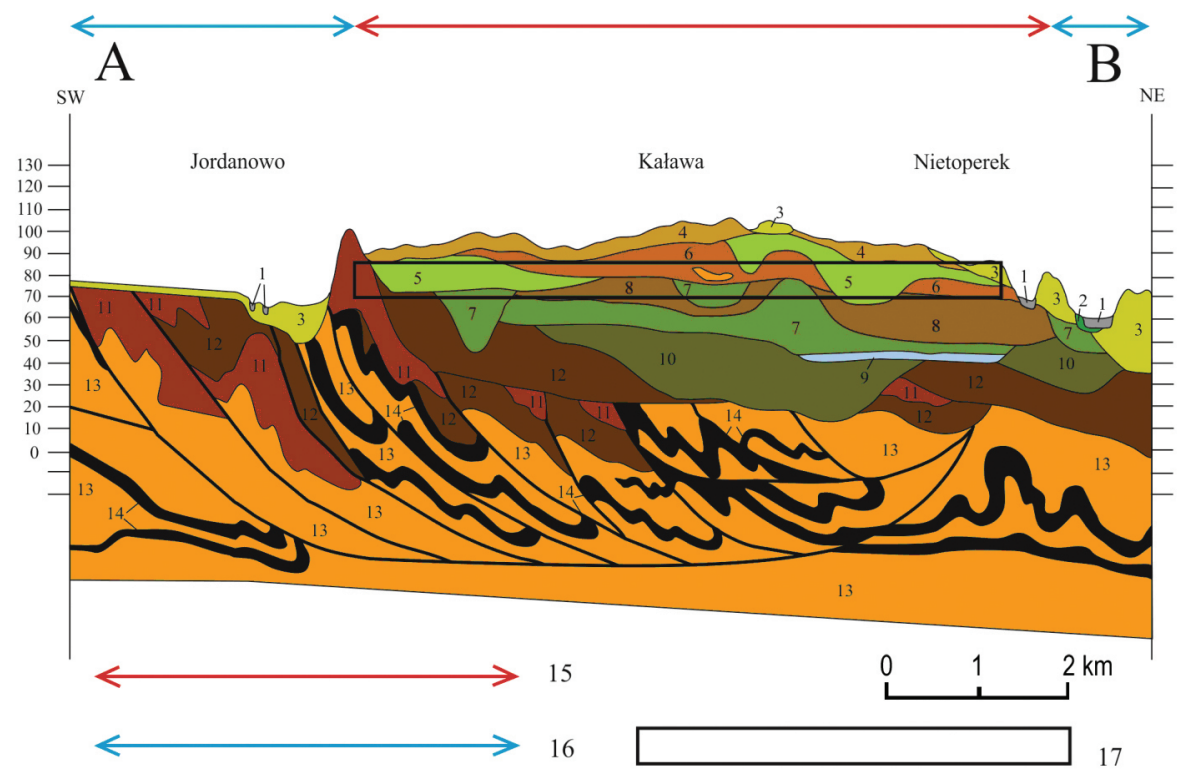

Ryc. 4. Przekrój geologiczny A-B

Fig. 4. Geological cross-section A-B

Objaśnienia: Wydzielenia litologiczne - holocen: 1 - torfy i namuły. Zlodowacenie Wisły: 2 - piaski i żwiry najwyższej terasy rzecznej; 3 - piaski, mułki i żwiry glacifluwialne; 4 - glina zwałowa. Stadiał Warty zlodowacenia Odry: 5 - piaski, mułki i żwiry glacifluwialne; 6 - glina zwałowa. Zlodowacenie Odry: 7 - piaski, mułki i żwiry glacifluwialne; 8 - glina zwałowa; 9 - mułki zastoiskowe. Zlodowacenia południowopolskie: 10 - piaski, mułki i żwiry glacifluwialne; 11 - żwiry, piaski, mułki, iły i gliny; 12 - glina zwałowa. Miocen: 13 - mułki, iły, piaski i węgiel brunatny; 14 - pokłady węgla brunatnego. Inne symbole: 15 - obszar MRU połączony podziemnym korytarzem; 16 - obszar MRU bez podziemnych połączeń komunikacyjnych; 17 - orientacyjna głębokość podziemnych tuneli.

Explanations: Lithostratigraphy - Holocene: 1 - peat and silt. Weichselian Glaciation: 2 - sand and gravel (fluvial, upper terrace); 3 - sand, silt and gravel (glaciofluvial); 4 - till. Warthe Stadial of Saale Glaciation: 5 - sand, silt and gravel (glaciofluvial); 6 - till. Saale Glaciation: 7 - sand, silt and gravel (glaciofluvial); 8 - till; 9 - silt (glaciolimnic). South-Polish Glaciations: 10 - sand, silt and gravel (glaciofluvial); 11 - gravel, sand, silt, clay, and till; 12 - till. Miocene: 13 - silt, clay, sand, and brown coal; 14 - brown coal seams. Other symbols: 15 - fortified region with tunnel-connected bunkers; 16 - fortified region with separate bunkers; 17 - approximate depth of underground tunnel.

Źródto: na podstawie: Salwa (2008) - zmodyfikowane.

Source: based on: Salwa (2008) - modified. 


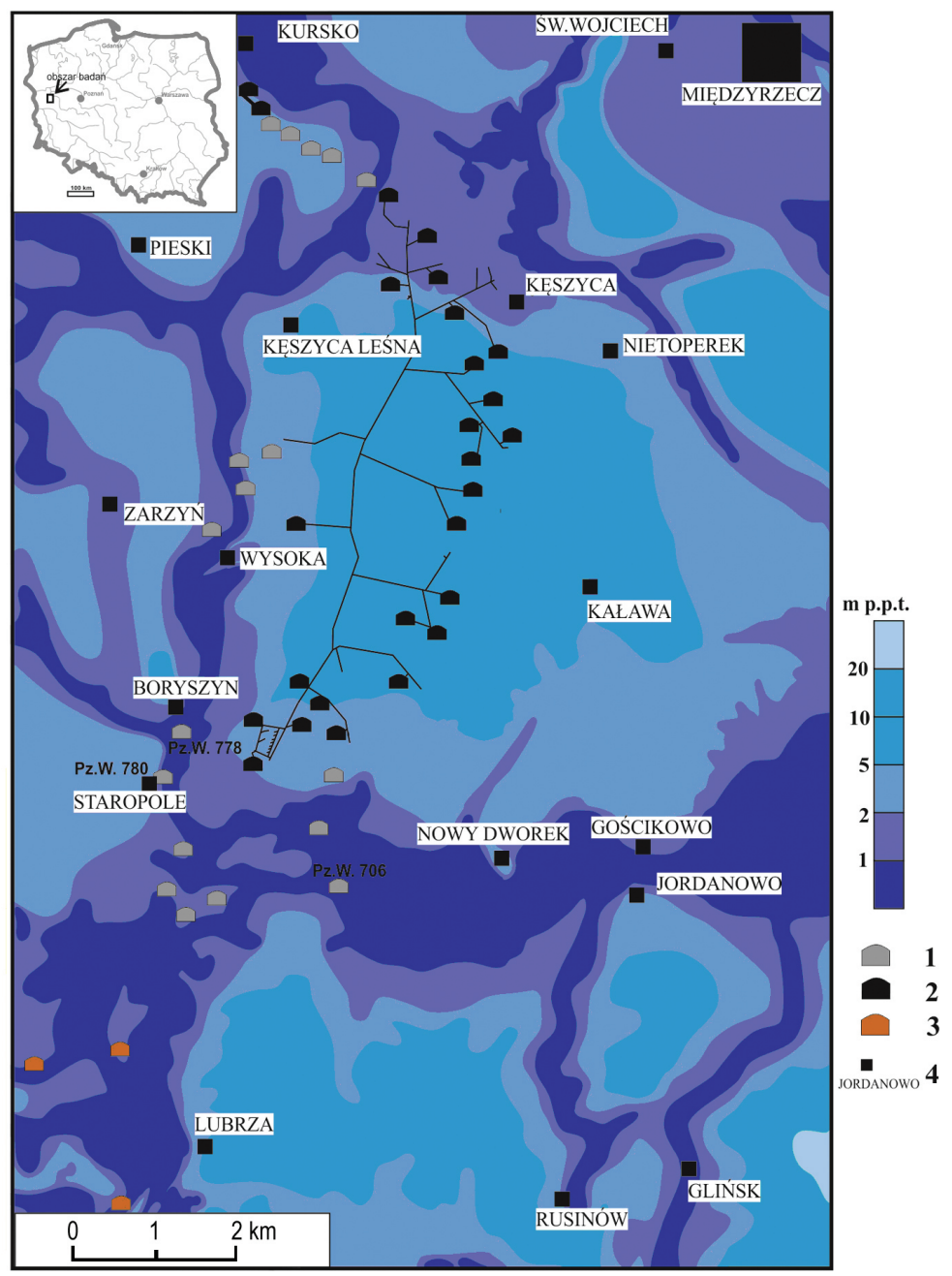

Ryc. 5. Mapa głębokości zwierciadła pierwszego poziomu wód podziemnych

Fig. 5. Hydrogeological sketch of the uppermost groundwater level

Objaśnienia: 1 - bunkry centralnego odcinka MRU niepołączone z sobą; 2 - bunkry centralnego odcinka MRU połączone tunelami komunikacyjnymi; 3 - bunkry południowego odcinka MRU; 4 - miejscowości. Explanations: 1 - separate bunkers of the central part of the fortified region; 2 - tunnel-connected bunkers of the central part of the fortified region; 3 - bunkers of the southern part of the fortified region; 4 - towns and villages. 
Jordanowa - Salwa 2008) lub innych osadach jeziornych, np. niedaleko Lubrzy (Chmal 2003b, Ratajczak-Szczerba i in. 2014). Miąższości torfów są zwykle niewielkie i sięgają średnio $1 \mathrm{~m}$, ale w okolicy Lubrzy jest to nawet ponad $5 \mathrm{~m}$ (Ratajczak-Szczerba i in. 2014).

\section{Cechy hydrogeologiczne obszaru}

Centralna Część MRU odwadniana jest w kierunku północnym przez Strugę Jeziorną oraz Paklicę, będącymi lewymi dopływami Obry. Skomplikowana budowa geologiczna obszaru centralnej części MRU powoduje dużą zmienność warunków hydrogeologicznych (Żynda 1989). Na omawianym obszarze występują dwa główne piętra wodonośne: czwartorzędowe i neogeńskie (Bobiński 2006b). W ich obrębie znajdują się od 2 do 5 poziomów wodonośnych. Na piętro czwartorzędowe składają się poziomy: gruntowy, międzyglinowy górny, międzyglinowy środkowy, podglinowy oraz utwory czwartorzędowe w obszarach intensywnych zaburzeń glacitektonicznych (Bobiński 2006b). Głębokość zalegania pierwszego poziomu wód podziemnych waha się w przedziale od poniżej $1 \mathrm{~m}$ do ponad $20 \mathrm{~m}$, uwzględniając ukształtowanie terenu, stopień skomplikowania budowy geologicznej i sezonowy przebieg wahań stanu wód podziemnych. Najpłycej wody podziemne zalegają w dolinach rzecznych oraz na równinach torfowych na głębokościach do 2,5 m p.p.t. (Żynda 1989; ryc. 5). Głębiej, w granicach $2 \mathrm{~m}$ do $5 \mathrm{~m}$ p.p.t., wody pierwszego poziomu zalegają w obrębie powierzchni zbudowanych z osadów fluwioglacjalnych - sandrach i terasie kemowej (ryc. 5). Najgłębiej zwierciadło pierwszego poziomu wód podziemnych znajduje się w obrębie wysoczyzn i moren czołowych, także spiętrzonych (ryc. 5). Piętro mioceńskie zasilane jest przez przesączające się wody z wyżej zalegających pięter czwartorzędowych, w miejscach, gdzie nie występują osady nieprzepuszczalne (Bobiński 2006b).

\section{Geomorfologiczne i geologiczne uwarunkowania MRU - dyskusja}

\section{Rola czynnika geomorfologicznego}

Analizując rozmieszczenie bunkrów w terenie, można zauważyć, że morfologia obszaru miała bardzo duży wpływ na lokalizację poszczególnych obiektów bojowych.

Obiekty połączone z sobą systemem podziemnym, a więc najważniejsza część MRU, zostały wybudowane w obrębie Wyspy Wysoczyznowej Kaławskiej oraz przylegających do niej moren czołowych (ryc. 2; ryc. 3). Większość obiektów została zbudowana w najwyższych partiach wysoczyzny, gdzie rzędne terenu przekraczają 100-120 m n.p.m. Różnice w wysokościach względnych pomiędzy wzniesieniami i obniżeniami terenu z kierunku wschodniego wynosiły do $70 \mathrm{~m}$, co zapewniało 
bardzo dobrą widoczność linii frontu. Najwyższe wzniesienia zostały umocnione systemem bunkrów, a na ich przedpolu, nachylonym w kierunku wschodnim, wybudowano dodatkowo zaporę przeciwpancerną ,zęby smoka” oraz rowy strzeleckie i okopy.

Południowy fragment centralnej części MRU, gdzie występują pojedyncze bunkry, znajduje się w obrębie Rynny Jordanowsko-Niesulickiej. Dno tego obniżenia wypełnione jest m.in. wodą jeziora Paklicko Wielkie. Przez ten obszar płyną także cieki wodne oraz kanały taktyczne wykopane podczas budowy MRU, na których stawiano zapory wodne, jazy bądź zastawy. Takie naturalne oraz wspomagane zabiegami hydrotechnicznymi obszary wodne lub podmokłe stanowiły naturalną przeszkodę. Obiekty bojowe stawiano w miejscach strategicznych, wzmacniając pozycje narażone na przekroczenie ich przez wroga. Za przykład można podać chociażby Pz.W. 706, który znajdował się przy zaporze i moście na kanale uchodzącym do Jeziora Paklicko Wielkie.

Schrony bojowe zlokalizowane w północnym odcinku centralnej części MRU znajdowały się w obrębie moren czołowych, na zapleczu zapór przeciwpancernych, rowów i kanałów taktycznych oraz Strugi Jeziornej. Znajdujące się najbardziej na północy analizowanego obszaru dwa schrony grupy warownej Schill połączone są z sobą systemem podziemnym. Zadaniem tej grupy było zamknięcie północnego skrzydła centralnego odcinka umocnień, a konkretnie kanałów taktycznych na południe od jeziora Kursko i blokującego je mostu taktycznego w Kursku. Podobnie jak w przypadkach opisanych wyżej, w tym rejonie znajdowały się także pojedyncze bunkry chroniące miejsca przecinające naturalne i sztuczne przeszkody.

Na zapleczu głównej linii umocnień znajdujących się na wysoczyźnie, w obrębie Rynny Staropolskiej, również rozlokowano pojedyncze schrony bojowe. Niemalże na całej długości osi tej rynny, podobnie jak w przypadku Rynny Jordanowsko-Niesulickiej, znajdują się jeziora, cieki wodne - naturalne i sztucznie pogłębiane - oraz kanały taktyczne utworzone sztucznie. Również tutaj pojedyncze, odosobnione schrony bojowe zlokalizowane są w miejscach przecinających te naturalne przeszkody - w okolicach dróg i mostów. Takimi obiektami były Pz.W. 780 oraz Pz.W. 778, zlokalizowane bezpośrednio przy mostach na Paklicy w Staropolu oraz w Boryszynie.

\section{Rola czynnika geologicznego}

Piaszczysto-żwirowe oraz gliniaste osady, w obrębie których zbudowano niemal wszystkie bunkry centralnej części MRU, klasyfikowane są jako posiadające korzystne warunki geologiczno-inżynierskie (wg PN-B-03020: 1981). Większość bunkrów bez infrastruktury podziemnej została zbudowana w utworach fluwioglacjalnych, w odróżnieniu od bunkrów z podziemnym systemem komunikacyjnym, które posadowiono w glinie zwałowej. Ma to związek z tym, że większość bunkrów 
niepołączonych z sobą tunelem komunikacyjnym miała za zadanie ochronę ważnych strategicznie miejsc. Należały do nich przepusty, mosty bądź drogi, w większości zlokalizowane w obrębie rynien glacjalnych lub innych obszarów, które najczęściej wypełnione są osadami fluwioglacjalnymi. Umocnienia połączone z sobą tunelem komunikacyjnym wybudowano natomiast na obszarze Wyspy Wysoczyznowej Kaławskiej, w lepszych warunkach geotechnicznych. Jeden obiekt (Pz.W. 778 w Boryszynie) został posadowiony w obrębie torfów i namułów, choć zapewne przed wybudowaniem bunkra zastosowano szereg zabiegów poprawiających nośność gruntu. W tym wypadku czynnik taktyczny wyraźnie zdominował uwarunkowanie geologiczne.

Bunkry na obszarze Wyspy Wysoczyznowej Kaławskiej wybudowano w obrębie nieskonsolidowanych glin piaszczystych zlodowacenia Wisły, często z domieszką frakcji żwirowej, występujących w stanie twardoplastycznym, półzwartym i zwartym (Bobiński 2006a) oraz piasków i żwirów moren czołowych, powyżej zwierciadła wód podziemnych. Z przekroju geologicznego poprowadzonego ok. 1-2 km na wschód wzdłuż linii MRU można odczytać, że najniższa kondygnacja umocnień przecina glacigeniczne utwory kilku zlodowaceń (ryc. 4). Niewykluczone, że podczas budowy obiektów MRU również natrafiono na osady mioceńskie, gdyż obszar pomiędzy Sulęcinem, Międzyrzeczem i Świebodzinem został silnie zaburzony glacitektonicznie w okresie zlodowaceń południowopolskich oraz w mniejszym stopniu środkowopolskich (Żynda 1967; Dyjor, Pruc 1978). Pierwotnie horyzontalnie warstwy zostały sfałdowane, tworząc synkliny i antykliny, pomiędzy którymi powstawały niekiedy płaszczyzny odkłuć, wzdłuż których następowały przesunięcia. W obrębie deformacji glacitektonicznych, a więc ok. 20-40 m pod bunkrami, znajdują się podziemne magazyny, koszary oraz główny tunel komunikacyjny (Miniewicz, Perzyk 1993). Pod bunkrami znajdował się szyb o średnicy od 3 do $5 \mathrm{~m}$ łączący przypowierzchniowe pomieszczenia $\mathrm{z}$ tunelem.

W tak zaburzonych warstwach parametry geotechniczne osadów mają dużą zmienność. Grunty mogą mieć bardzo zróżnicowane wartości poszczególnych parametrów, zmieniające się przestrzennie na niewielkich odległościach. Może się tak dziać zwłaszcza w glinach, które często wykazują zmienności w obrębie jednego poziomu, wynikające z dużej poziomej i pionowej zmienności litologicznej i wilgotnościowej. Podczas budowy systemu podziemnego konieczne było zastosowanie odwodnienia, co powodowało polepszenie właściwości wytrzymałościowych osadów (przejście ze stanu twardoplastycznego w półzwarty i półzwartego w zwarty). Ważnym aspektem w kontekście budowy podziemnych tuneli był wpływ naprężeń geostatycznych na konstrukcję bunkrów. Przy założeniu, że średni ciężar objętościowy gruntów w podłożu waha się w zakresie $17-20 \mathrm{kN} / \mathrm{m}^{3}$, a przy tym grubość nadkładu zmienia się w zakresie 20-40 m, można oszacować wartości tych naprężeń na ok. $600 \mathrm{kPa}$. Wartość ta z całą pewnością musiała być uwzględniona w zwymiarowaniach samej konstrukcji bunkrów, m.in. poprzez zastosowanie odpowiednich grubości ich ścian.

Ważnym aspektem w kontekście budowy obiektów MRU były warunki hydrogeologiczne (ryc. 5). Większość obiektów połączonych głębokim podziemnym sys- 
temem komunikacyjnym, znajdujących się głównie na wysoczyźnie, zlokalizowana jest w miejscach, gdzie zwierciadło wód podziemnych znajduje się na głębokości większej niż $5 \mathrm{~m}$ p.p.t. Taka lokalizacja niosła z sobą korzyści, gdyż dwie najwyższe i zarazem najważniejsze kondygnacje bunkrów znajdowały się ponad poziomem wód podziemnych (ryc. 6). Podziemny tunel, który został wybudowany 20-40 m p.p.t., musiał znaleźć się poniżej poziomu wód podziemnych, dlatego miał systemy odwadniające. Korytarze zostały lekko nachylone w celu umożliwienia grawitacyjnego spływu wód. Posiadały także skutecznie działający system wentylacji. Jedno bądź wielokondygnacyjne obiekty wolnostojące w większości zbudowano w ważnych strategicznie miejscach, często w bezpośrednim sąsiedztwie jezior, rzek i kanałów taktycznych. Budowanie podziemnego systemu w tych obszarach, gdzie zwierciadło wód podziemnych znajduje się bardzo płytko, stanowiłoby skomplikowane przedsięwzięcie i wymagałoby ogromnego nakładu pracy związanego z odpompowywaniem i odwadnianiem pomieszczeń i tuneli, a także z panującą wilgocią. Często stosowane na linii MRU spiętrzenia wody spowodowałyby też dynamiczne zmiany warunków geotechnicznych i hydrogeologicznych podłoża gruntowego. Wobec tego w tych miej-

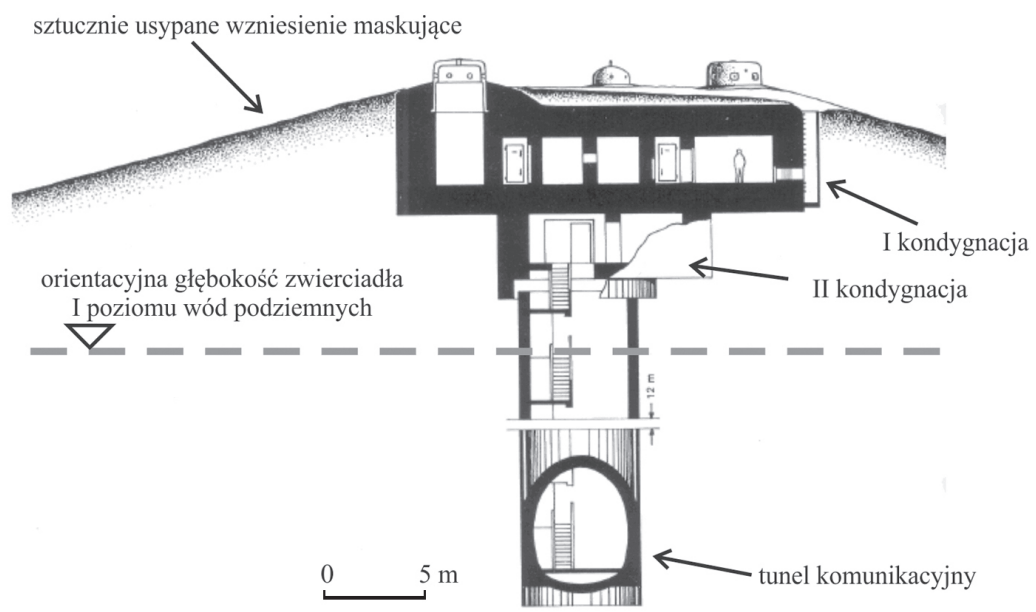

Ryc. 6. Rysunek przedstawiający dwukondygnacyjny schron Pz.W. 717 z szybem doprowadzającym do podziemnego tunelu komunikacyjnego

Fig. 6. Sketch of a two-level bunker Pz.W. 717 with a staircase leading to the basal tunnel Źródto: opracowanie własne na podstawie: Miniewicz, Perzyk (1993)-zmodyfikowane.

Source: author's own elaboration based on: Miniewicz, Perzyk (1993) - modified. 
Tab. 1. Tabela typów odporności schronów budowanych przez wojska niemieckie Table 1. Table of the resistance types of the shelters built by German troops

\begin{tabular}{|c|c|c|c|c|c|}
\hline \multirow{2}{*}{$\begin{array}{c}\text { Typ } \\
\text { Type }\end{array}$} & \multicolumn{3}{|c|}{$\begin{array}{c}\text { Grubość żelbetonu [m] } \\
\text { Reinforced concrete thickness [m] }\end{array}$} & \multicolumn{2}{c|}{$\begin{array}{c}\text { Grubość pancerza [cm] } \\
\text { Armor thickness [cm] }\end{array}$} \\
\cline { 2 - 6 } & $\begin{array}{c}\text { Ściany zewnętrzne } \\
\text { External walls }\end{array}$ & $\begin{array}{c}\text { Ściany wewnętrzne } \\
\text { Interior walls }\end{array}$ & Stropy / Ceilings & Kopuła / Dome & Płyty / Plate \\
\hline D & 0,3 & 0,3 & 0,3 & 5,0 & $2-5$ \\
\hline C & 0,6 & 0,3 & 0,5 & 6,0 & $6-7$ \\
\hline B1 & 1,0 & 0,5 & 0,8 & $12-16$ & 10 \\
\hline B alt & 1,5 & 0,8 & 1,5 & 25 & 20 \\
\hline B neu & 2,0 & 0,8 & 2,0 & 25 & 20 \\
\hline A1 & 2,5 & 1,0 & 2,2 & 42 & $25-35$ \\
\hline A & 3,5 & 1,0 & 3,5 & 60 & $25-52$ \\
\hline
\end{tabular}

Źródto: opracowanie własne na podstawie: Short (2004).

Source: author's own elaboration based on: Short (2004).

scach postawiono pojedyncze głównie jednokondygnacyjne obiekty, a podziemne tunele wybudowano w miejscach, gdzie zwierciadło wód znajdowało się niżej.

Ogólnie można stwierdzić, że całość systemu centralnej części MRU, złożonego z bunkrów budowanych przy powierzchni oraz podziemnych tuneli, budowana była w zmiennych, często skomplikowanych warunkach geologiczno-inżynierskich i hydrogeologicznych. Różnice w geotechnicznych parametrach ośrodka geologicznego, w którym powstał system podziemny niwelowano grubością ścian i stropów samych bunkrów i tuneli. Zdecydowana większość bunkrów (40z 46 obiektów na obszarze badań) posiadała odporność B alt, co odpowiada 1,5 m grubości ścian zbudowanych z żelbetonu (tab. 1). Takie „obramowanie” tuneli stanowiło dobrą osłonę, sprawiając, że skomplikowana budowa geologiczna obszaru nie stanowiła problemu dla lokalizacji obiektów. Należy także pamiętać, że budowa całego systemu MRU przebiegała bardzo szybko, a na samo wykonanie bunkrów i tuneli przeznaczono olbrzymie nakłady finansowe, co powodowało, że niedogodność ich lokalizacji w związku z niekorzystnymi warunkami geologiczno-inżynierskimi (przynajmniej lokalnie) schodziła na dalszy plan.

\section{Wnioski}

W niniejszym artykule po raz pierwszy przeprowadzono szczegółową analizę geomorfologiczno-geologiczną obszaru MRU. Przeprowadzone badania terenowe, laboratoryjne oraz prace kameralne pozwoliły na sformułowanie następujących wniosków: 
1. Obiekty MRU zlokalizowane są w dwu sytuacjach geomorfologicznych: głównie w obrębie i bezpośrednim sąsiedztwie wzniesień wysoczyzny polodowcowej oraz moren czołowych, a także w sąsiedztwie dolin i mis jeziornych. Schrony bojowe MRU zbudowane są najczęściej w piaszczysto-żwirowych osadach morenowych bądź fluwioglacjalnych, glinach zwałowych oraz częściowo w spiętrzonych glacitektonicznie osadach neogeńskich. Taka lokalizacja gwarantowała dobre warunki geoinżynierskie.

2. Głównym czynnikiem warunkującym rozmieszczenie obiektów MRU była morfologia terenu. Bunkry połączone podziemnym systemem komunikacyjnym znajdują się na wzniesieniach - przede wszystkim w najwyższych partiach Wyspy Wysoczyznowej Kaławskiej, której wysokości wahają się pomiędzy 100 i 120 m n.p.m. Ta lokalizacja niosła z sobą korzyści przede wszystkim odnośnie do dobrej widoczności linii frontu. Odosobnione bunkry są natomiast zlokalizowane w obniżeniach terenu - głównie w rynnach polodowcowych. W ich przypadku wzmocnienie pozycji obronnych wynikało z sąsiedztwa przeszkód wodnych: jezior, rzek i bagien. $Z$ przyczyn niekorzystnych warunków geoinżynierskich te budowle reprezentują mniej rozbudowane (głównie w pionie) konstrukcje.

3. Przypowierzchniowe osady, w obrębie których posadowiono budowle militarne MRU, to zwłaszcza plejstoceńskie piaszczyste, piaszczysto-żwirowe oraz gliniaste osady glacigeniczne. Niekiedy przy powierzchni na skutek glacitektoniczego wyciśnięcia znajdują się starsze, mioceńskie osady ilasto-piaszczyste, w obrębie których występują pokłady węgla brunatnego. W obniżeniach terenu występują holoceńskie osady organiczne oraz rzeczne i jeziorne.

Studium to dowodzi, że warunki geologiczne nie były kluczowe jeśli chodzi o lokalizację bunkrów. Analiza wykazała, że aspekty litologiczne były drugorzędnymi czynnikami warunkującymi rozmieszczenie schronów MRU. Przede wszystkim warunki hydrogeologiczne mogły odgrywać rolę w lokalizacji bunkrów, ponieważ obiekty połączone podziemnym systemem komunikacyjnym zostały wybudowane na obszarach o głębszym zaleganiu zwierciadła wód podziemnych, a płytko posadowione, jednokondygnacyjne obiekty wolnostojące zlokalizowano w sąsiedztwie kanałów i rzek, gdzie warunki hydrogeologiczne są mniej korzystne.

\section{Podziękowania}

Bardzo serdecznie chciałbym podziękować prof. dr. hab. Tomaszowi Zielińskiemu za liczne, cenne uwagi, dyskusje oraz wskazówki, które pomogły mi w przygotowaniu niniejszej pracy, oraz Robertowi Jurdze za udostępnienie archiwalnych materiałów dotyczących Międzyrzeckiego Rejonu Umocnionego, znajdujących się w jego prywatnej kolekcji. 


\section{Literatura}

Bartczak E., 2003a, Objaśnienia do szczegótowej mapy geologicznej Polski 1: 50 000. Arkusz Świebodzin (502), Ministerstwo Środowiska i Państwowy Instytut Geologiczny, Warszawa.

Bartczak E., 2003b, Szczegótowa mapa geologiczna Polski 1: 50 000. Arkusz Świebodzin (502), Państwowy Instytut Geologiczny, Warszawa.

Bartkowski T., 1956, Z «agadnień geomorfologicznych okolicy Międzyrzecza, Badania Fizjograficzne nad Polską Zachodnią, 3, Poznań.

Bartkowski T., 1964, Morfogeneza Watu Bukowieckiego (Ziemia Międzyrzecka), PTPN, Prace Komisji Geograficzno-Geologicznej, 4 (3), Poznań.

Bartkowski T., 1967, O formach strefy marginalnej na Nizinie Wielkopolskiej, PTPN, Prace Komisji Geograficzno-Geologicznej, 7 (1), Poznań.

Bartkowski T., 1970, Wielkopolska i Środkowe Nadodræe, PWN, Warszawa.

Bobiński W., 2006a, Warunki podtoża budowlanego, [w:] W. Bobiński, I. Bojakowska, P. Dobek, A. Pasieczna, H. Tomassi-Morawiec, Objaśnienia do mapy geośrodowiskowej Polski 1:50 000. Arkus: Międzyrzecz Wielkopolski (466).

Bobiński W., 2006b, Warunki wodne, [w:] W. Bobiński, I. Bojakowska, P. Dobek, A. Pasieczna, H. Tomassi-Morawiec, Objaśnienia do mapy geośrodowiskowej Polski 1: 50 000. Arkusz Międzyræecz Wielkopolski (466).

Chmal R., 2003a, Objaśnienia do szczegótowej mapy geologicznej Polski 1:50 000, arkusz Toporów (501), Ministerstwo Środowiska i Państwowy Instytut Geologiczny, Warszawa.

Chmal R., 2003b, Szczegótowa mapa geologiczna Polski 1: 50 000. Arkusz Toporów (501), Państwowy Instytut Geologiczny, Warszawa.

Ciuk E., 1995, Zarys budowy geologicznej i rowwoju deformacji glacjalnych utworów trzecioræędowych rejonu Sieniawy Lubuskiej i jego otoczenia, [w:] VIII Glacitectonics Symposium, Zielona Góra.

Dyjor S., Pruc K., 1978, Budowa geologicะna zaburæonej glacitektonicænie strefy Sieniawy, Acta Univ. Wratislaviensis, 313, Prace Geol.-Mineral., 5, 255-289.

Jurga R.M., 2012a, Międzyrzecki Rejon Umocniony dla poczqtkujqcych. Cæęśc I, Wyd. Pracownia R.M. Jurga, Zielona Góra.

Jurga R.M., 2012b, Międzyrzecki Rejon Umocniony dla poczq̨tkująych. Cæęş́ II, Wyd. Pracownia R.M. Jurga, Zielona Góra.

Jurga R.M., Kędryna A.M., 2005, Festungsfront Oder-Warthe Bogen. Katalog, Wyd. Donjon, Boryszyn.

Jurga R.M., Lisiecki L., 2015, Panzerwerk Pæ.W. 717: Werkgruppe Scharnhorst: [Reiseführer], Wyd. Pracownia R.M. Jurga, Zielona Góra.

Kondracki J., 2002, Geografia regionalna Polski, Wydawnictwo Naukowe PWN, Warszawa.

Kozarski S., 1995, Deglacjacja pótnocno-zachodniej Polski. Warunki i transformacja geosystemu 20-10 ka BP, IGiPZ PAN, Dokumentacja Geograficzna, 1, 1-82.

Krüger J., Kjær K.H., 1999, A data chart for field description and genetic interpretation of glacial diamicts and associated sediments - with examples from Greenland, Iceland, and Denmark, Boreas, $28,386-402$. 
Leibner G., 2000, Die Festung „Oder-Warthe-Bogen”, Wyd. Ingrid Haupt, Buchholz.

Marks L., 2005, Pleistocene glacial limits in the territory of Poland, Przegląd Geologiczny, 53, 10 (2), 988-993.

Marks L., Dzierżek J., Janiszewski R., Kaczorowski J., Lindner L., Majecka A., Makos M., Szymanek M., Tołoczko-Pasek A., Woronko B., 2016, Quaternary stratigraphy and palaeogeography of Poland, Acta Geologica Polonica, 66 (3), 403-427.

Miall A.D., 1977, A review of the braided-river depositional environment, Earth-Science Reviews, $13,1-62$.

Miniewicz J., Perzyk B., 1993, Międzyrzecki Rejon Umocniony, Wyd. ME-GI, Warszawa.

Ratajczak-Szczerba M., 2011, Budowa wewnętrzna moreny czotowej glacitektonicznie spiętrzonej kompleksu Dębowej Góry - stanowisko Krostkowko, Landform Analysis, 16, 115-123.

Ratajczak-Szczerba M., Sobkowiak-Tabaka I., Okuniewska-Nowaczyk I., 2014, Morfologia dna i osady denne kopalnego sbiornika w rynnie jordanowsko-niesulickiej koto Lubræy, Pojezierze Lubuskie, Studia Limnologica et Telmatologica, 8 (2), 71-80.

Salwa S., 2008, Szczegótowa mapa geologiczna Polski 1: 50 000. Arkusz Międzyrzecz Wielkopolski (466), Państwowy Instytut Geologiczny, Warszawa.

Short N., 2004, Germany's West Wall: The Siegfried Line, Osprey Publishing, Oxford.

Skompski S., 1981, Stratygrafia osadów czwartoræędowych Ziemi Lubuskiej, Biuletyn Instytutu Geologicznego, 322, 151-163.

Studencki M., 2000, Szczegótowa mapa geologicæna Polski 1:50 000. Arkusz Trzemeszno Lubuskie (467), Państwowy Instytut Geologiczny, Warszawa.

Winnicki J., 2004, Wpływ środkowoplejstoceńskich struktur glacitektonicznych i rynien subglacjalnych na rześbę w pótnocnej części Pojezierza Lubuskiego (zachodnia Polska), Przegląd Geologiczny, 52 (12), 1144-1150.

Zieliński T., Pisarska-Jamroży M., 2012, Jakie cechy litologiczne warto kodować, a jakie nie?, Przegląd Geologiczny, 60 (7), 387-398.

Żynda S., 1967, Geomorfologia przedpola moreny czotowej stadiatu poznańskiego na obszarze Wysoczyzny Lubuskiej, PTPN, Prace Komisji Geograficzno-Geologicznej, 8, Poznań.

Żynda S., 1989, Międzyrzecki Rejon Umocniony jako obiekt fizycznogeograficznych badań potencjalnego obszaru sktadowania odpadów promieniotwórczych, [w:] E. Biderman (red.), Energetyka jqdrowa - cztowiek - srodowisko, Poznań, 331-340.

Mateusz Mleczak

Uniwersytet im. Adama Mickiewicะa w Poznaniu

Instytut Geologii

ul. Bogumita Krygowskiego 12, 61-680 Poznań

mateusz.mleczak@amu.edu.pl 